\title{
Histone 1 Antibody Measurement
}

National Cancer Institute

\section{Source}

National Cancer Institute. Histone 1 Antibody Measurement. NCI Thesaurus. Code C112293.

The determination of the amount of histone 1 antibody present in a sample. 